\title{
Automotive Product Development Process (APDP) Strategy by Integrating Six Sigma to Reduce the Cost of Quality
}

\author{
S.N.Teli ${ }^{1,}$ Dr.V.S.Majali ${ }^{2,}$ Dr.U.M.Bhushi ${ }^{3,}$ Sanjay Patil ${ }^{4}$ \\ ${ }^{1 .}$ Associate Professor \& HOD -Mech. Engg., SCOE, Kharghar, Navimumbai Maharashtra, India \\ Research scholar GIT Belgaum, VTU Belgaum, Karnataka \\ 2. Professor \& HOD-Mech. Engg.Dept., GIT, Belgaum, Karnataka \\ ${ }^{3 .}$ Principal - Sahyadri College of Mangalore Engineering \& Management, Mangalore, Karnataka, India \\ 4. PG Student - Mech. Engg. Dept.SCOE, Kharghar, Navimumbai Maharashtra, India
}

\begin{abstract}
Six Sigma Seeks To Improve The Quality Of Process Outputs By Identifying And Removing The Causes Of Defects (Errors) And Minimizing Variability In Manufacturing And Business Processes. It Uses A Set Of Quality Management Methods, Including Statistical Methods, And Creates A Special Infrastructure Of People Within The Organization ("Black Belts", "Green Belts", Etc.) Who Are Experts In These Methods. The Term Six Sigma Originated From Terminology Associated With Manufacturing, Specifically Terms Associated With Statistical Modeling Of Manufacturing Processes. The Maturity Of A Manufacturing Process Can Be Described By A Sigma Rating Indicating Its Yield, Or The Percentage Of Defect-Free Products It Creates. A Six Sigma Process Is One In Which 99.99966\% Of The Products Manufactured Are Statistically Expected To Be Free Of Defects (3.4 Defects Per Million). This Paper Focus Mainly To Reduce The Cost Of Quality For Automobile Industry By Using Six Sigma Tools. There Are Three Groups Of Quality Costs: External Failure Costs: Warranty Claims \& Service Costs, Internal Failure Costs: The Cost Of Labour, Material Associated With Scrapped Parts, And Rework. Cost Of Appraisal \& Inspection: These Are Materials For Samples, Test Equipment, Inspection Labour Cost, Quality Audits, Etc.
\end{abstract}

Key word: Six Sigma, Cost of Quality, APDP

\section{Introduction:}

Six Sigma projects follow two project methodologies inspired by Deming's Plan-Do-Check-Act Cycle. These methodologies composed of five phases each, bear the acronyms DMAIC and DMADV.DMAIC is used for projects aimed at improving an existing business process. DMAIC is pronounced as "duh-may-ick". DMADV is used for projects aimed at creating new product or process designs. DMADV is pronounced as "duh-mad-vee". The DMAIC project methodology has five phases: Define the problem, the voice of the customer, and the project goals, specifically. Measure key aspects of the current process and collect relevant data. Analyze the data to investigate and verify cause-and-effect relationships. Determine what the relationships are, and attempt to ensure that all factors have been considered. Seek o ut root cause of the defect under investigation.

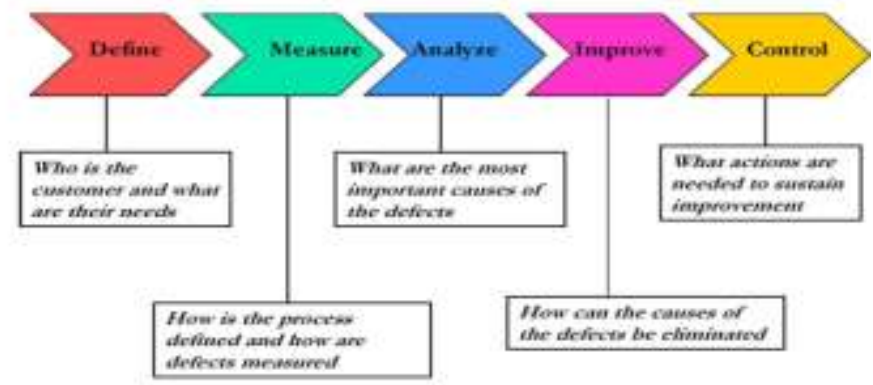

Fig 1: Phases of Sixsigma

II. Objectives:

- Build-in DFSS tools (i.e., DOE, FMEA) to process deliverables.

- Establish clear requirements.

- Look for inventive ways and design alternatives to satisfy requirements.

- Establish risk mitigation plans.

- Optimize product design and function considering total lifecycle costs.

- Optimize cost/benefit associated with manufacturing tolerances.

- Verify fulfillment of requirements established in initial program phases. 


\section{Six Sigma Application / Advantages:}

- Leading companies have implemented Six Sigma and realized gainful results. Motorola has reported over US $\$ 17$ billion in savings from Six Sigma as of 2006.

- By the late 1990s, about two-thirds of the Fortune 500 organizations had begun Six Sigma initiatives with the aim of reducing costs and improving quality.

- Helps in producing what is needed, when it is needed, with a minimum amount of materials, equipment, labor and space.

- "Prime Directive" - to continually seek out and eliminate waste and wasteful practices.

- Lean Six Sigma helps to, improve quality, eliminate waste ,reduce lead time, reduce total costs.

- Helps to continually seek out and eliminate unsafe operating conditions and practices in every aspect of our Business and every process within our .

- Operations and to constantly, and consistently, enhance Health/Welfare, Safety and Environmental concerns and issues.

- The Benefits Always Include Increased Market Share, Lowered Cost, Higher Profits and Happier Customers (And Shareholders)

\section{Six Sigma Is Really Three Things:}

- A statistical measure of the performance of a process or product.

- A goal that reaches near perfection for performance improvement.

- A system of management to achieve lasting business leadership and world-class performance.

In other words...

- Six Sigma is not merely a quality initiative; it is a business initiative.

- Six Sigma is a smarter way to manage a business or a department.

- Six Sigma puts the customer first and uses facts and data to drive better decisions.

- Six Sigma is a total management commitment and philosophy of excellence, customer focus, process improvement, and the rule of measurement rather than gut feel.

\section{The Six Themes Of Six Sigma:}

4.1 Genuine focus on the Customer: Six Sigma improvements are defined by their impact on customer satisfaction and value.

4.2 Data and Fact Driven Management Processes are Where the Action Is: Mastering a Process is a way to build competitive advantage.

4.3 Processes are Where the Action Is: Mastering a Process is a way to build competitive advantage.

4.4 Proactive Management: Focus on problem prevention rather than firefighting. Question the current process.

4.5 Boundary less Collaboration: Improved communication, less competition between groups and divisions. 4.6 Drive for Perfection, Tolerance of Failure: Effective risk management, but must accept .

\section{Tools Of Six Sigma:}

- Voice of the Customer: Quality Functional Deployment (QFD) matrix.

- Creative Thinking: Brainstorming sessions.

- Statistics: Statistical Process Control, Analysis of Variance (ANOVA), Design of Experiments

- Process Design/Redesign: Process mapping

- Process Management: Process Owner role

- Balanced Scorecards: Establishing metrics for organization

- Continuous Improvement

\section{The Six Sigma Dmadv Framework: Refer Table-I}

Table -1 DMADV frame work

\begin{tabular}{|c|l|l|}
\hline & Definitions for Process Design/Redesign & \multicolumn{1}{c|}{ OUTPUTS } \\
\hline \multirow{2}{*}{} & $\bullet$ Identify specific or broad problem & $\bullet$ Project Charter \\
・ Definegoal/change vision & $\bullet$ SIPOC diagram \\
• Clarify scope \& customer requirements & $\bullet$ Voice of Customer \\
\hline
\end{tabular}




\begin{tabular}{|c|c|c|}
\hline 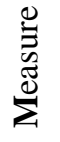 & $\begin{array}{l}\text { - Measure performance to requirements } \\
\text { - Gather process efficiency data }\end{array}$ & $\begin{array}{l}\text { - Identify measurements } \\
\text { - Data Collection Plan } \\
\text { - Gage R\&R/Process Capability }\end{array}$ \\
\hline 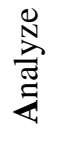 & $\begin{array}{l}\text { - Identify "best practices" } \\
\text { - Assess process design } \\
\text { - Refine requirements }\end{array}$ & $\begin{array}{l}\text { - Analyze data collected } \\
\text { - Regression/Design of Experiments } \\
\text { - Hypothesis Testing }\end{array}$ \\
\hline $\begin{array}{l}\frac{5}{\tilde{v}} \\
\stackrel{0}{0}\end{array}$ & $\begin{array}{l}\text { - Design new process } \\
\text { - Implement new process, structures and } \\
\text { systems }\end{array}$ & $\begin{array}{l}\text { - Generate solutions } \\
\text { - Cost-Benefit Analysis/Risk } \\
\text { Management } \\
\text { - Pilot Process } \\
\text { - Implementation Plan } \\
\end{array}$ \\
\hline$\stackrel{\substack{0 \\
D}}{D}$ & $\begin{array}{l}\text { - Establish measures \& reviews to } \\
\text { maintain performance } \\
\text { - Correct problems as needed }\end{array}$ & $\begin{array}{l}\text { - Evaluate results/ Key Learnings } \\
\text { - Process Change Management } \\
\text { - Process Monitoring } \\
\text { - Documentation and } \\
\text { Standardization occasional } \\
\text { setbacks. }\end{array}$ \\
\hline
\end{tabular}

VII. Six Sigma Tools \& Techniques: Refer Table II Table- II Six Sigma Tools \& Techniques

\begin{tabular}{|c|l|}
\hline & Six Sigma Tools and Techniques \\
\hline \multirow{3}{*}{ Generating Solutions } & - Brainstorming \\
& - Affinity Diagrams \\
& - Interrelationship Digraph (ID) \\
\hline Cost-Benefit Analysis & - NPV \\
\hline \multirow{3}{*}{ Selecting the Solution } & - Solution Statements \\
& - Multivoting \\
& - Radar Chart \\
\hline \multirow{3}{*}{ Risk Assessment } & - Force Field Analysis \\
& - Process Simulation/ Sol. Validation \\
& - Poka Yoke \\
& - Process Decision Program Chart (PDPC) \\
\hline \multirow{3}{*}{ Implementation on Planning } & - Activity Network Diagram(AND) \\
& - Tantt \\
\hline \multirow{2}{*}{ Pilot } & - Pilot techniques: Offline pilot, Selected times, items or \\
& \\
&
\end{tabular}

\section{Six Sigma Tools Using In Apdp:}

8.1 Concept Engineering: What It Is: A methodology for Synthesizing the Voice of the Customer and filtering needs, wants and desires into a set of saleable design inputs. What it Does: Facilitates understanding of the customers environment and the conversion of that customer understanding into prioritized functional product requirements. Applicable Design For Excellence. Review: Design Input Review. Process Requirements Review, Design Output Review.

8.2 SIPOC: What It Is: A process analysis tool that looks at Suppliers, Inputs, Processes, Outputs, and Customers. What it Does: Used to set boundaries for a process and helps eliminate/reduce scope creep. Applicable Design for Excellence Review: Design Input Review. Process Requirements Review, Design Output Review Comments: Useful general purpose tool that can be applied to defining new milestone reviews and sub processes as well as checking procedures.

8.3 Basic Statistics and Graphical Tools: What It Is: Basic concepts of statistics and Minitab statistical software applied to concepts of capability, voice of the process and specification. What it does: Use to analyze 
data, understand product and process performance Process Specifications Review Includes Dot plots, Run Charts, Pareto Diagrams, Boxplots, Scatterplots, Check Sheets.

8.4 Measurement Systems Analysis (MSA): What It Is: Measurement Systems Analysis (also known as Gauge $\mathrm{R} \& \mathrm{R})$ MSA determines how much of the observed process is due to measurement system variation. What it does: Identifies which design parameters are measurable and the approach for the measuring them. Design Input Review. Process Requirement Review, Design Output Review, Process Specifications Review, Design Verification Review, Design Transfer Review. Complements Concept Engineering which identifies which design parameters are most/least important

8.5 Process Capability: What It Is: Process Capability analysis is a graphical or statistical tool that visually or mathematically compares actual process performance to the performance standards established by the customer. What it does: The outputs of Process Capability analysis are CP and CPK values; $\mathrm{CP}$ is an index that measures the spread of the distribution compared to specifications, CPK in an index that measures the center of the distribution compared to specifications. Process Specifications Review, Design Verification Review, Design Transfer Review. Useful in identifying potential causes of defects and where specifications may be too tight

8.6 Statistical Tolerance: What It Is: Develop working knowledge of both linear and non linear tolerance analysis, establish the link to process capability into the model, and optimize designs based on process capabilities for each component in the assembly.

8.7 Design for Manufacturability: What It Is: A set of platform and architectural rules that should be applied to ensure robust, manufacturable products. What it does: Provides terminology, structure and heuristics to guide the design process. Design Output Review, Process Specifications Review.

8.8 Modular Design: What It Is: Establish the aim of the overall system in terms of performance and prices; classify and analyze subsystems of the manufacturer's design and their competitors; measure the design's complexity and those of the competitors' products; index subsystems design and those of direct competitors against standard baselines of function and cost. aim of the overall system in terms of performance and price. What it does: Identifies opportunities for standardization to improve quality and costs Design Input Review. Process Requirements Review, Design Output Review, Process Specifications Review

8.9 Critical Parameter Management: What It Is: Methodology to identify parameters that are critical based on customer needs develop linkage of critical parameters from the customer through to product/process of design and control. What it does: Drives a system integration mindset using quantitative tools. Results in scorecards of Critical-to-Function specifications from the system level down to the component and mfg process level. Design Output Review, Process Specifications Review.

8.10 Risk Assessment: What It Is : A design risk assessment is the act of determining potential risk in a design process, either in a concept design or a detailed design. It provides a broader evaluation of the design beyond just CTQs (Critical to Quality) and will eliminate possible failures and reduce the impact of potential failures. This ensures a rigorous systematic examination in the reliability of the design and captures system level risk. Design Input Review. Process Requirements Review, Design Output Review, Process Specifications Review, Design Verification Review, Design Transfer Review.

8.11 Design FMEA: What It Is: Design Failure Mode and Effects Analysis(DFMEA) is a disciplined approach used to identify possible failures of a product or service and then determine the frequency and impact of the failure What it does: DFMEA is used to recognize and evaluate the potential product or process failure and its causes associated with the designing and Manufacturing of a product .Design Output Review \&Design Verification Review.

8.12 Hypothesis Testing: What It Is: Hypothesis Testing refers to the process of using statistical analysis to determine if the observed differences between 2 or more samples are due to random chance (as stated in the null hypothesis) or to true differences in the samples (as stated in the alternate hypothesis).

Process Specifications Review, Design Verification Review \& Design Transfer Review.

8.13 Confidence Intervals: What It Is: The interval estimate of the mean value or standard deviation. A confidence interval is a range of likely values of population parameter. Since we cannot calculate the true value 
of the parameter, the confidence interval allows us to guess its value based on the sample data. Process Specifications Review, Design Verification Review \& Design Transfer Review.

8.14 Sampling Statistics: What It Is: Sampling is the practice of gathering a subset of the total data available from a process or a population to draw conclusions about the total population. What it does: Many manufacturing process outputs are verified by sampling instead of $100 \%$ inspection. Design Output Review, Process Specifications Review, Design Verification Review\& Design Transfer Review.

8.15 T Test: What It Is: A t-test is a statistical tool used to determine whether a significant difference exists between the means of two distributions or the mean of one distribution and a target value. Process Specifications Review, Design Verification Review\& Design Transfer Review.

8.16 Analysis of Variance (ANOVA):What It Is: ANOVA, a calculation procedure to allocate the amount of variation in a process and determine if it is significant or is caused by random noise. What it does: ANOVA used to investigate and model the relationship between a response variable and one or more independent variables. However, ANOVA differs from regression in two ways; the independent variables are qualitative (categorical), and no assumption is made about the nature of the relationship. Process Specifications Review, Design Verification Review \&Design Transfer Review.

8.17 Design of Experiments (DOE): What It Is: A Design of Experiment (DOE) is a structured organized method for determining the relationship between the factors (inputs) and the responses (outputs) of a process. DOE allows for the simultaneous study of the effects that several factors may have on a process. What it does: Characterizes a process and the variables that need to be carefully controlled for robust design. Provide a starting point for optimization Process Specifications Review

8.18 Robust Design: What It Is: Robust Design method also called Taguchi method pioneered by Dr. Genichi Taguchi, greatly improves engineering productivity by consciously considering the noise factors and the cost of failure to ensure customer satisfaction. Process Specifications Review, Design Verification Review, Process Requirements Review, Design Output Review\& Process Specifications.

8.19 Quality Loss Function: Review, Design Verification Review \&Design Transfer Review.

8.20 Multiple Regressions: What It Is: A method of determining the relationship between a continuous output (response variable) and several inputs (predictors). What it does: Multiple regression techniques are used to investigate and model the relationship between a response variable and one or more predictors. Design Output Review, Process. Specifications Review, Design Verification Review \& Design Transfer Review

8.21 Response Surface Methods (RSM): What It Is: Response Surface Methods are used to examine the relationship between one or more response variables and a set of quantitative experimental variables or factors. What it does: These methods are often employed after you have identified a "vital few" controllable factors and you want to find the factor settings that optimize the response. Designs of this type are usually chosen when you suspect curvature in the response surface \& Process Specifications Review.

8.22 Reliability Engineering: What It Is: Reliability Engineering is a method of ensuring that a product will perform its intended function under stated conditions for a specified period of time. Design Output Review, Process Specifications Review\& Design Verification Review.

8.23 Capability Assessment: What It Is: A comparison study between a process performance and its specifications. Design Verification Review \& Design Transfer Review

8.24 Multi Variable Study: What It Is: A method of characterizing the baseline capability of a process while in a production mode. In a multivariable study, data is collected for a short period of time and analyzed to determine capability, stability and relationships between inputs and outputs.

8.25 Validation Overview: What It Is: Establishing documented evidence which provides a high degree of assurance that a specific process will consistently produce a product meeting its predetermined specifications and quality attributes.. A process validation may include but not limited to Installation Qualification, Operational Qualification, and Performance Qualification. 
8.26 Process Controls: What It Is: Process Controls includes methods of monitoring and ensuring that a product or a process perform as designed. What it does: Process control methods include SPC used to monitor the shifts in the process. Engineering Controls (Poka-yoka) used to prevent human errors.

8.27 Acceptance Sampling Techniques :What It Is: Optimize the sample size to represent the population based on process capability, while minimizing the costs of sampling or inspection \& Design Transfer Review

\section{Case Study: Reduction In Exhaust Pipes \& Silencer Failures}

\subsection{Project Definition: Warranty Improvements : Refer Table III}

\section{Table- III Project Character}

\begin{tabular}{|c|c|c|c|c|}
\hline $\begin{array}{l}\text { Mission Of } \\
\text { Goal }\end{array}$ & \multicolumn{4}{|c|}{ Enhancing vehicle reliability to match $1^{\text {st }}$ hemisphere market level } \\
\hline Initiative & \multicolumn{4}{|c|}{$\begin{array}{l}\text { Reduction in Exhaust Pipes \& silencer failure by } 80 \% \text { from base level ( eliminate safety } \\
\text { critical issues) }\end{array}$} \\
\hline Linkage & \multicolumn{4}{|c|}{ Improve customer satisfaction in terms of improving product reliability \& thus enhance sales } \\
\hline Scope & \multicolumn{4}{|c|}{ Exhaust system failure across all models } \\
\hline \multirow[t]{2}{*}{ Metrics } & From & $2.86 \%$ & To & $.57 \%$ \\
\hline & $\begin{array}{l}\text { Interim } \\
\text { milestones/ } \\
\text { metrics }\end{array}$ & $\begin{array}{l}\text { 1)Establish Team } \\
\text { 2)Problem Definition-D } \\
\text { 3)Critical failure mode identification \& } \\
\text { Measure -M } \\
\text { 4)Root Cause Analysis-A } \\
\text { 5)Corrective Actions - I } \\
\text { 6)Control \& Integration-C }\end{array}$ & & $\begin{array}{l}1^{\text {st }} \text { April } \\
28^{\text {th }} \text { April } \\
15^{\text {th }} \text { May } \\
31^{\text {st }} \text { May30 } 30^{\text {th }} \text { June } \\
15^{\text {th }} \text { July }\end{array}$ \\
\hline $\begin{array}{l}\text { Other } \\
\text { benefits } \\
\text { targeted }\end{array}$ & Tangible & $\begin{array}{l}\text { Warranty incidents reduction by } 80 \% \text { \& } \\
46 \text { lakhs reduction (Warranty Cost) }\end{array}$ & Intangible & $\begin{array}{l}\text { Customer } \\
\text { satisfaction } \\
\text { Brand Image }\end{array}$ \\
\hline Review by & $\begin{array}{l}\text { Mentor } \\
\text { weekly }\end{array}$ & Board Members - Fortnightly & MD-Month & \\
\hline Approvals & \multicolumn{4}{|l|}{$\mathrm{CEO}$} \\
\hline
\end{tabular}

\subsection{Problem Solving Methodology: Refer Table IV}

\begin{tabular}{|c|c|c|c|c|c|c|c|}
\hline \multicolumn{8}{|c|}{ Table IV Impact Score } \\
\hline & \multirow{2}{*}{ Aspect } & \multirow{2}{*}{$\begin{array}{l}\text { Weightag } \\
\mathrm{e}^{\text {W }}\end{array}$} & \multirow{2}{*}{$\begin{array}{l}\text { Rating } \\
(1,3,9)\end{array}$} & \multirow{2}{*}{\begin{tabular}{|l} 
Score \\
(WeightX \\
Rating)
\end{tabular}} & \multicolumn{3}{|c|}{ Rating Guidlines } \\
\hline & & & & & 1 & 2 & 3 \\
\hline \multicolumn{8}{|c|}{ IMPACT } \\
\hline 1 & $\begin{array}{l}\text { Impact on } \\
\text { the } \\
\text { customer }\end{array}$ & .3 & 9 & 2.7 & $\begin{array}{lr}\text { No effect or } \\
\text { No } \text { Direct } \\
\text { Effect }\end{array}$ & & $\begin{array}{l}\text { Direct effect on } \\
\text { the Final } \\
\text { Customers/Intern } \\
\text { al Customer }\end{array}$ \\
\hline 2 & $\begin{array}{l}\text { Money } \\
\text { Saving } \\
\text { Potential }\end{array}$ & .3 & 3 & .9 & $\begin{array}{l}\text { Less Than } 10 \\
\text { Lakhs }\end{array}$ & $\begin{array}{l}\text { Between } 10 \text { to } \\
50 \text { Lakhs }\end{array}$ & $\begin{array}{l}\text { More Than } 50 \\
\text { Lakhs }\end{array}$ \\
\hline 3 & $\begin{array}{l}\text { Frequenc } \\
y \text { of the } \\
\text { Problem }\end{array}$ & .2 & 9 & 1.8 & $\begin{array}{ll}\text { Less } & \text { Than } \\
1000 \text { to } 5000 \\
\text { PPM }\end{array}$ & $\begin{array}{l}\text { More than } \\
5000 \text { PPM }\end{array}$ & $\begin{array}{ll}\text { More } & \text { than } \\
5000 P P M & \end{array}$ \\
\hline 4 & $\begin{array}{l}\text { Linkage } \\
\text { to the } \\
\text { Business } \\
\text { Goals }\end{array}$ & .2 & 9 & 1.8 & $\begin{array}{l}\text { Very Weak } \\
\text { Linkage }\end{array}$ & $\begin{array}{l}\text { Direct } \\
\text { Linkage to } \\
\text { Company's } \\
\text { Business } \\
\text { Goals }\end{array}$ & $\begin{array}{l}\text { Direct Linakge } \\
\text { to Company's } \\
\text { Business Goals }\end{array}$ \\
\hline & & 1 & 7.2 & 72 & & & \\
\hline
\end{tabular}




\subsection{Complexity: Refer Table V}

\begin{tabular}{|c|c|c|c|c|c|c|c|}
\hline 1 & $\begin{array}{l}\text { Knowledge About the } \\
\text { Solution }\end{array}$ & .3 & 3 & .9 & $\begin{array}{l}\text { Solution is } \\
\text { Known requires } \\
\text { only } \\
\text { implementation }\end{array}$ & $\begin{array}{l}\text { Solution is known for } \\
\text { a similar situation but } \\
\text { needs to be tried out } \\
\text { for the current } \\
\text { situation. }\end{array}$ & $\begin{array}{l}\text { Solution is not known } \\
\text { to be found out. }\end{array}$ \\
\hline 2 & Data Availability & .3 & 3 & .9 & $\begin{array}{l}\text { All data is } \\
\text { ready available }\end{array}$ & Requires little effort & $\begin{array}{l}\text { No data is available we } \\
\text { need to put up a process } \\
\text { for data collection }\end{array}$ \\
\hline 3 & Man power Required & .2 & 9 & 1.8 & $\begin{array}{l}\text { Concerned } \\
\text { Executive is } \\
\text { sufficient for } \\
\text { implementation }\end{array}$ & $\begin{array}{l}\text { Requires help from } \\
\text { one more function }\end{array}$ & $\begin{array}{l}\text { Requires support from } \\
\text { more than one function }\end{array}$ \\
\hline 4 & Time Required & .2 & 3 & .6 & $\begin{array}{l}\text { Can be } \\
\text { implemented } \\
\text { within a Month }\end{array}$ & $\begin{array}{l}\text { Upto } 3 \text { months is } \\
\text { required }\end{array}$ & $\begin{array}{l}\text { Min. } 6 \text { Months is } \\
\text { required }\end{array}$ \\
\hline 5 & & 1 & & 4.2 & & & \\
\hline & \multicolumn{3}{|l|}{ Complexity Score } & 46.7 & & & \\
\hline
\end{tabular}

9.4 Problem Solving Methodology Selection Grid:

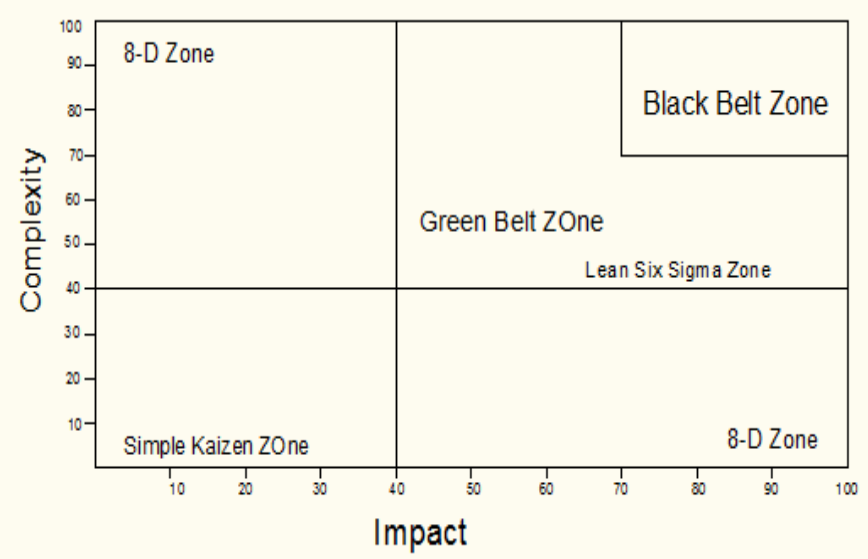

Fig.2: Problem Solving Methodology

\subsection{Business Case: Refer Table VI}

Table VI Business Case

\begin{tabular}{|l|l|l|}
\hline Period & Threats & Opportunities \\
\hline $\begin{array}{l}\text { Short Term } \\
\text { ( 3 to 6 Months) }\end{array}$ & $\begin{array}{l}\text { Increase of warranty claim } \\
\text { Failure with a month and } \\
\text { very early Kms Vehicle } \\
\text { offroad due to failure }\end{array}$ & $\begin{array}{l}\text { Reducing of warranty } \\
\text { claim } \\
\text { customer confidence } \\
\text { \& satisfaction Increase } \\
\text { of turnaround time \& } \\
\text { reliability }\end{array}$ \\
\hline $\begin{array}{l}\text { Long Term } \\
\text { 3 to 5 Years) }\end{array}$ & $\begin{array}{l}\text { Loss of Market share } \\
\text { due to warranty failure } \\
\text { compared with competitor } \\
\text { warranty }\end{array}$ & $\begin{array}{l}\text { Gaining \& Maintaining } \\
\text { the market share with } \\
\text { customer delightness. }\end{array}$ \\
\hline
\end{tabular}




\subsection{Project Tracker : Refer Table VII}

Table VII Project Tracker

\begin{tabular}{|c|c|}
\hline Phase & Activity \\
\hline Define & Charter Preparation \\
\hline Measure & $\begin{array}{ll}\text { - } & \text { Warranty Data Collection } \\
\text { - } & \text { Base line Data stratification } \\
\text { - } & \text { Process Capability } \\
\text { - } & \text { Process Flow Chart } \\
\text { - } & \text { C and E Matrix }\end{array}$ \\
\hline Analyze & $\begin{array}{ll}\text { - } & \text { FMEA } \\
\text { - } & \text { Hypothesis Test } \\
\text { Regression Analysis }\end{array}$ \\
\hline Improve & $\begin{array}{ll}\text { - } & \text { DOE/RSM } \\
\text { - } & \text { Process Capability } \\
\text { - } & \text { Poka Yoke } \\
\end{array}$ \\
\hline Control & $\begin{array}{ll}\text { - } & \text { Control Plans } \\
\text { - } & \text { Control Charts } \\
\end{array}$ \\
\hline
\end{tabular}

\subsection{Flow Chart - SIPOC}

\begin{tabular}{|c|c|c|c|}
\hline Supplier & Input & Process & Output \\
\hline & Silencer \& Pipes & $\begin{array}{l}\text { Finished Products from Supplier } \\
\text { Fitment in Vehicle } \\
\text { Quality Checks by OEM } \\
\text { Vehicle to RSO/Dealer } \\
\text { Vehicle to Customer } \\
\text { Vehicle operation \& Feed Back }\end{array}$ & Vehicle \\
\hline
\end{tabular}

Fig. 3: Flow Chart - SIPOC Diagram 


\section{Conclusion:}

A six sigma initiative focused on reducing the costs of poor quality enables management to reap increased customer satisfaction \& bottom line results. A six sigma initiative focused on reducing the costs of poor quality enables management to reap increased customer satisfaction \& bottom line results. Cost of quality is measure of quality level. Cost of quality is correlated with company's bottom line \& lean six sigma is the process of asking questions that lead to tangible \& quantifiable answers that ultimately produce profitable results. Cost of appraisal \& inspection: these are materials for samples, test equipment, inspection labour cost, quality audits, etc.Typical north American company's average sigma level is around 3 sigma. In other words, 25 to $30 \%$ of most quality is measure of quality level. Cost of quality is correlated with company's bottom line \& lean six sigma is the process of asking questions that lead to tangible \& quantifiable answers that ultimately produce profitable results.

There are four groups of quality costs:

- External failure costs: warranty claims \& service costs

- Internal failure costs: the cost of labour, material associated with scrapped parts, and rework.

- Cost of appraisal \& inspection: these are materials for samples, test equipment, inspection labour cost, quality audits, etc.

Typical north American company's average sigma level is around 3 sigma. In other words, 25 to $30 \%$ of most company's annual revenue gets chewed up by their cost of quality. Thus if company can improve its quality by 1 sigma level, its net income will increase hugely, approximately $10 \%$ net income improvement, see the table VIII .

Table VIII Six Sigma Vs COQ

\begin{tabular}{|l|l|l|l|}
\hline $\begin{array}{l}\text { Sigma } \\
\text { Level }\end{array}$ & \% Good & $\begin{array}{l}\text { PPM } \\
\text { /DPMO }\end{array}$ & $\begin{array}{l}\text { Cost of Quality } \\
\text { as \% of sales }\end{array}$ \\
\hline 2 & 95.45 & 45500 & Over 40\% \\
\hline 3 & 99.73 & 2700 & $25-40 \%$ \\
\hline 4 & 99.9937 & 63 & $15-25 \%$ \\
\hline 5 & 99.999943 & 0.57 & $5-15 \%$ \\
\hline 6 & 99.9999998 & 0.002 & Less than 1\% \\
\hline
\end{tabular}

Furthermore, when level of process complexity increases, (e.g. output of one sub process feed to input of another sub process), the rolled throughput yield of the process will decrease, then the final outgoing quality level will decline, and the cost of quality will increase. For example if company satisfies its single process yield with $93.93 \%$ as good, 3 sigma level, it may end up with an unacceptable final yield with which represents Unacceptable final yield which represents very high cost of quality. Thus when quality of products and services get even the smallest notch lower from the intended quality level, one can expect huge difference in the revenues. Making use of six sigma concept helps keep the quality of the product controlled in a pleasing way to avoid unnecessary downsizing of one's overall profits. In cases where business quality costs starts to limit incoming profits, the best way to save everything is employing the six sigma methodology to the entire operation. This can not only boost the quality of the business output, but the morale of the employees as well.

\section{References:}

[1] Adams, Cary W.; Gupta, Praveen; Charles E. Wilson (2003). Six Sigma Deployment. Burlington, MA: Butterworth-Heinemann.

[2] Breyfogle, Forrest W. III (1999). Implementing Six Sigma: Smarter Solutions Using Statistical Methods. New York, NY: John Wiley \& Sons.

[3] De Feo, Joseph A.; Barnard, William (2005). JURAN Institute's Six Sigma Breakthrough and Beyond - Quality Performance Breakthrough Methods. New York, NY: McGraw-Hill Professional.

[4] Hahn, G. J., Hill, W. J., Hoerl, R. W. and Zinkgraf, S. A. (1999) The Impact of Six Sigma Improvement-A Glimpse into the Future of Statistics, The American Statistician, Vol. 53, No. 3, pp. 208-215.

[5] Keller, Paul A. (2001). Six Sigma Deployment: A Guide for Implementing Six Sigma in Your Organization. Tucson, AZ: Quality Publishing.

[6] Pande, Peter S.; Neuman, Robert P.; Roland R. Cavanagh (2001). The Six Sigma Way: How GE, Motorola, and Other Top Companies are Honing Their Performance. New York, NY: McGraw-Hill Professional.

[7] Pyzdek, Thomas and Paul A. Keller (2009). The Six Sigma Handbook, Third Edition. New York, NY: McGraw-Hill.

[8] Snee, Ronald D.; Hoerl, Roger W. (2002). Leading Six Sigma: A Step-by-Step Guide Based on Experience with GE and Other Six

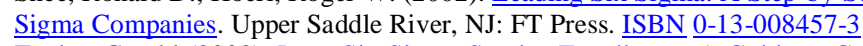

[9] Taylor, Gerald (2008). Lean Six Sigma Service Excellence: A Guide to Green Belt Certification and Bottom Line Improvement. New York, NY: J. Ross Publishing.

[10] Tennant, Geoff (2001). SIX SIGMA: SPC and TQM in Manufacturing and Services. Aldershot, UK: Gower Publishing, Ltd. 